\title{
Changing the cultural model to create a new development dynamic in old industrial regions.
}

Jean-Louis Dethier, Avenue Bois Becquet, 16 1300 Wavre (Belgium)

Jean-Louis Dethier is consultant in management and strategy for public and non profit sector. He practises systemic analysis for modelling and studying human and organisational systems. (change management).

\section{Keywords}

Industrial Regions - development - unemployment - recovery - culture modelling cultural change - behaviours - perceptions - values - beliefs -

\section{Abstract}

Thanks to coal and iron, Wallonia was from $19^{\text {th }}$ till the second half of $20^{\text {th }}$ century one of the most prosperous regions of Europe. Heavy industries have created thousand of jobs, however the hard pay and working conditions that very strong Trade Unions fought and succeeded to improve. This has deeply printed its history and the culture of its population and leaders.

As in many other places, those industries have been declining from World War II. Walloon Coal mines closed down, and iron, mechanical, glass, transport industries, which were exporting throughout the world, lost their competitiveness from 1973. Today, the few which survive provide less and less jobs, and for more and more skilled workers.

From 1950, Belgian Government and ECSC have invested billions of Euros to cover the losses of coal mining, to maintain the jobs and activities they provided and their suppliers and subcontractors. Important economic infrastructures were created, hoping to attract international investments, with to weak results to compensate the loss of thousands of jobs. From 1993, European Fund for Regional Develoment provided important funding to Wallonia, especially to its most populated Province (Hainaut).

In 1980, the Walloon Region was created, with large autonomy and legislative power. Many people and lobbies proposed various plans for recovering. However, few was done, Governments and Economic and Social Council being frightened at that time by stopping complaining and turning towards the future.

In the last 90's, the social and economic situation of Wallonia was one of the worst in the EU (15 Member States): GDP and employment rate were 75\% of the average. In some cities, unemployment was higher than $50 \%$, even more for young people. The new Government published a "Contrat d'Avenir", a document listing a hundred of projects and a goal : to reach the European average in GDP and employment 10 years later. In the meantime, several development plans have been launched. But these figures stay roughly unchanged. 
Today, nevertheless the general economic depression, the Walloon dynamic looks improving: the growth rate, the creation of jobs are better than... in Flanders (one of the leading regions of Europe in economic development). Some signs of recovery appear.

In 2005, the Destree Institute (Private Research Centre working on Wallonia and Walloon identity - www.destree.eu) created the "Collège regional de Prospective", a group of 30 persons, representing by third public, private sector and citizen organisations). Very quickly, the College admitted that the need was not to build a new economic development plan for Wallonia (after many others), but to answer the question : why did we take so many years to react, and why do the plans not succeed?

To answer those questions, we decided to decode the Walloon cultural model. This could point out the collective behaviours preventing development and facilitate to find out those who could generate development and reconversion.

The analytic model we utilised was designed by C. Van Remoortere and implemented by J.L. Dethier :

\section{How to influence development}

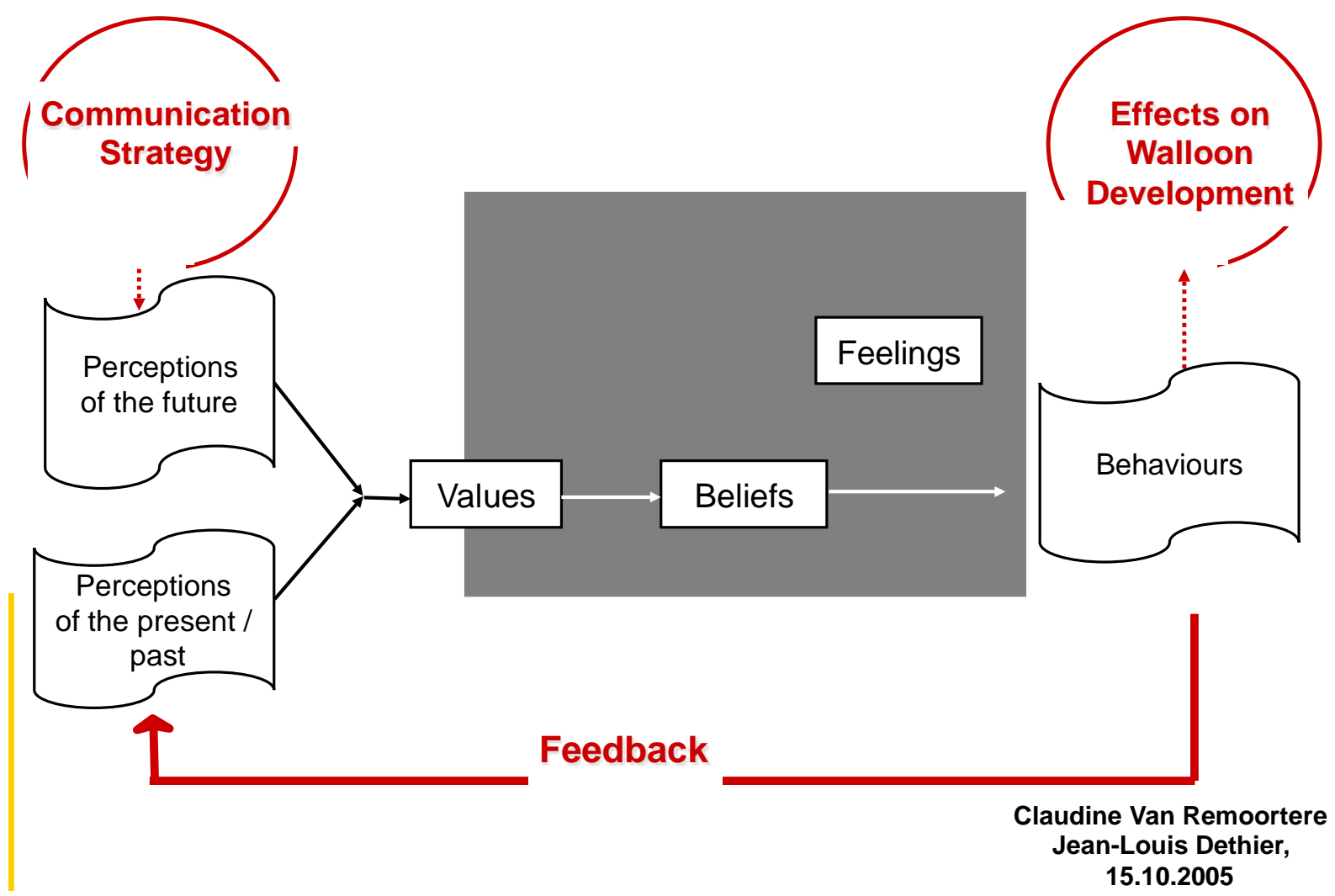


Various situation in various field were analysed using this model by groups of about five members of the College, one of them bringing information about the situation (problematic situation, stakeholders, interactions among them, solution).

According to the analysis model, characteristics of each situation were identified in terms of behaviours, perceptions, values, beliefs and feelings shared by the players, which had generated them (example follows). 
The results of all the analysed situations were consolidated.

Recurrent perceptions, values, beliefs and behaviours were indentified.

This which produced the following synthesis of the collective unadapt behaviours, preventing development:

Inadapted collective behaviors

\begin{tabular}{|c|c|c|c|}
\hline PERCEPTIONS & VALUES & BELIEFS & BEHAVIOURS \\
\hline $\begin{array}{l}\text { The State is providing } \\
\text { for risks }\end{array}$ & $\begin{array}{c}\text { Security } \\
\text { Liberty of actions } \\
\text { Modesty }\end{array}$ & $\begin{array}{l}\text { I know what I have, not } \\
\text { what I will have. } \\
\text { Happiness is in local } \\
\text { life }\end{array}$ & $\begin{array}{l}\text { Cantonment on own } \\
\text { territory }\end{array}$ \\
\hline $\begin{array}{l}\text { The State takes in } \\
\text { charge the needs and } \\
\text { solves the problems }\end{array}$ & $\begin{array}{c}\text { Security } \\
\text { Stability } \\
\text { Personal life } \\
\text { environment }\end{array}$ & Future is uncertain & Fixation on immediacy \\
\hline $\begin{array}{l}\text { If I move, my } \\
\text { environment changes }\end{array}$ & $\begin{array}{l}\text { Personal fullfillment } \\
\text { To be at peace } \\
\text { Security and conformity }\end{array}$ & $\begin{array}{l}\text { Change is rissky. } \\
\text { Efforts are not rewarded }\end{array}$ & $\begin{array}{l}\text { Actors adopt reactive } \\
\text { defensive strategies (3) }\end{array}$ \\
\hline $\begin{array}{l}\text { The public authorities } \\
\text { hesitate to punish } \\
\text { infractions. They will } \\
\text { find a way not to } \\
\text { punish. }\end{array}$ & $\begin{array}{c}\text { Immediate welfare } \\
\text { Individual liberty } \\
\text { Power } \\
\text { Money }\end{array}$ & $\begin{array}{l}\text { I will always be ok. } \\
\text { Prevention is always } \\
\text { better than repression. }\end{array}$ & $\begin{array}{l}\text { Acceptation of certain } \\
\text { transgressions }\end{array}$ \\
\hline $\begin{array}{l}\text { There will always be } \\
\text { pillars. }\end{array}$ & $\begin{array}{c}\text { Security } \\
\text { Recognition }\end{array}$ & $\begin{array}{l}\text { Pillars system is } \\
\text { durable. Others are } \\
\text { ennemies }\end{array}$ & $\begin{array}{l}\text { Pillars and other } \\
\text { established groups are } \\
\text { mainly interested by } \\
\text { cake's distribution (5) }\end{array}$ \\
\hline
\end{tabular}


Links between regional development and this culture were also highlighted:

\section{Effects on development (traditional)}

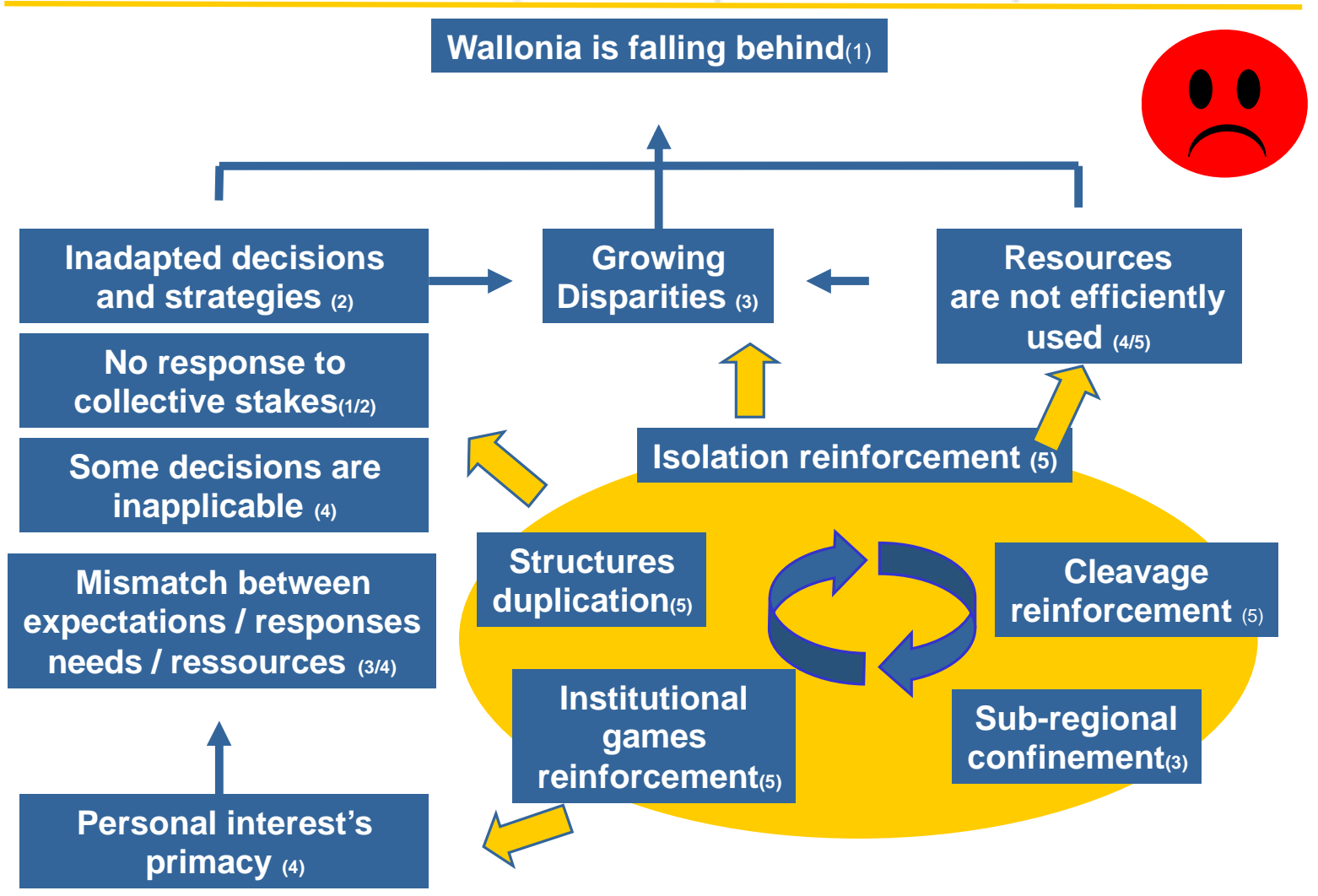


Vice versa, the College developed than another model of the behaviours to implement, in order to facilitate and accelerate change.

\section{Desired collective behaviors}

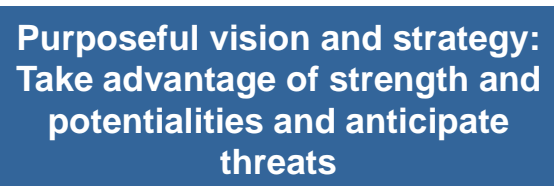

Investment in people, in immaterial resources

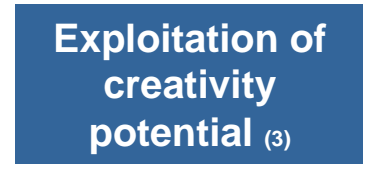

Support of innovative initiatives(1)

Anticipation Innovation (3/5)

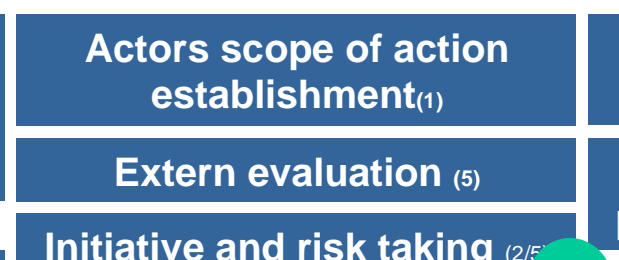

Participation, deliberation (4)

Actors societal preoccupations(2)

\section{inith} valorization of the other (4)
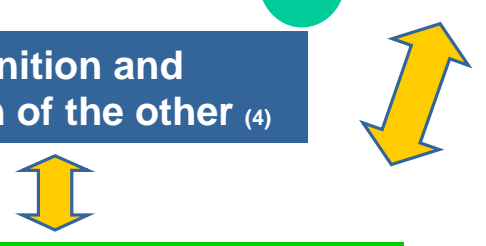

\section{True cooperation between actors} $(1 / 2 / 5)$

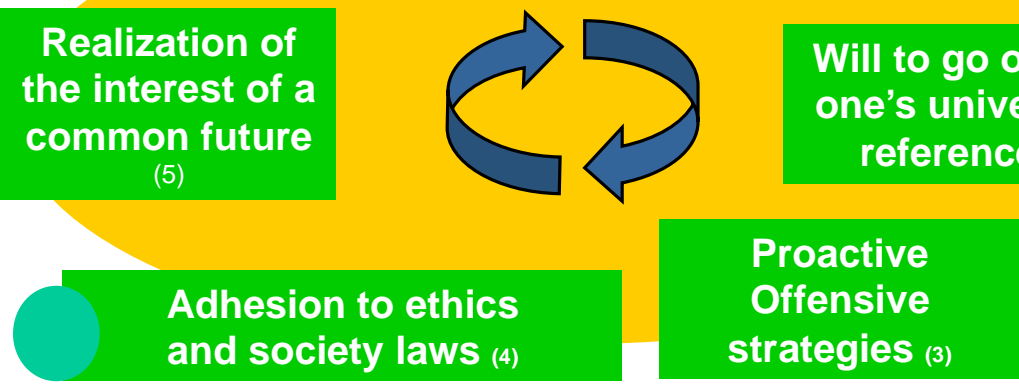

These analyses were shown and discussed with a collection of selected personalities, who agreed its interpretation was correct.

This experience seems interesting to report as a systemic analysis of the common shared behaviours of the Walloon leaders and their effect on economic an social regional development.

The contribution will give some details and examples concerning the analysis method, and will also discuss about what the College can do to facilitate the cultural change, starting from what have already done since 2010 and what were the reactions of the (system of) players. 